\title{
OPTIMASI PEMBUATAN KARAGENAN DARI RUMPUT LAUT APLIKASINYA UNTUK PERENYAH BISKUIT
}

\author{
Anes Agustin ${ }^{1}$, Aprillia Intan Saputri ${ }^{1}$, Harianingsih ${ }^{2 *}$ \\ ${ }^{1}$ Jurusan Teknik Kimia, Fakultas Teknik, Universitas Sebelas Maret \\ Jl. Kentingan No. 36 A Surakarta \\ ${ }^{2}$ Jurusan Teknik Kimia, Fakultas Teknik, Universitas Wahid Hasyim \\ J1. Menoreh Tengah X/22, Sampangan, Semarang 50236. \\ "Email: harianingsih@,unwahas.ac.id
}

\begin{abstract}
Abstrak
Indonesia merupakan negara kepulauan yang memiliki wilayah laut yang luas dan kaya akan sumber daya alam salah satunya adalah rumput laut. Rumput laut merupakan komoditas perikanan penting di Indonesia. Sampai saat ini sebagian besar rumput laut umumnya diekspor dalam bentuk bahan mentah berupa rumput laut kering, sedangkan hasil olahan rumput laut seperti agar-agar, karagenan, dan alginat masih diimpor dalam jumlah yang cukup besar dengan harga yang tinggi. Karaginan merupakan senyawa yang termasuk kelompok polisakarida galaktosa hasil ekstraksi dari rumput laut. Sebagian besar karaginan mengandung natrium, magnesium, dan kalsium yang dapat terikat pada gugus ester sulfat dari galaktosa dan kopolimer 3,6-anhydro-galaktosa. Karaginan biasa digunakan pada industry crackers, wafer, kue, dan jenis-jenis biskuit lainnya untuk mendapatkan tekstur yang renyah perlu ditambahkan karaginan.

Tujuan dari pembuatan penelitian ini adalah untuk mengetahui pemanfaatan rumput laut sebagai bahan tambahan makanan, membuat tepung karagenan dengan bahan baku berupa rumput laut jenis Eucheuma Cottoni, serta membandingan kerenyahan antara biskuit yang diberi tepung karagenan dengan biskuit yang tidak diberi tepung karagenan.Proses pembuatan tepung karagenan dengan bahan baku rumput laut Eucheuma Cottoni ini dilakukan melalui beberapa tahap, yaitu proses pengeringan, perendaman karaginan, ekstraksi karaginan, presipitasi, penepungan dan pengayakan. Kemudian dilakukan pembandingan dengan membuat dua sampel biskuit yang diberi dan tanpa diberi tepung karaginan, terakhir dilakukan pengamatan.Hasil analisis menunjukkan bahwa proses pembuatan tepung karagenan didapatkan rendemen rata-rata sebesar 24,30\%. Kadar air yang terkandung dalam tepung karagenan sebesar 10,32\%, kadar abu sebesar 15,81\%, dan kadar sulfat sebesar 26,14\%. Nilai kekuatan gel tepung karagenan sebesar $42,70 \mathrm{gram} / \mathrm{cm}^{2}$. Pada tepung karagenan tidak ditemukan pengotor maupun kandungan etanol sehingga tepung karagenan layak untuk dikonsumsi. Dari hasil uji organoleptik yang diambil dari 20 responden menyatakan bahwa biskuit yang diberi tepung karagenan lebih renyah dibandingkan dengan biskuit yang tidak diberi tepung karagenan.
\end{abstract}

Kata kunci: karagenan, kerenyahan, rumput laut

\section{PENDAHULUAN}

Rumput laut merupakan tumbuhan laut jenis alga, sejenis ganggang multi seluler golongan divisi thallophyta. Berbeda dengan tanaman sempurna pada umumnya, rumput laut tidak memiliki akar, batang, dan daun. Jenis rumput laut sangat beragam, mulai dari yang berbentuk bulat, pipih, tabung atau seperti ranting dahan bercabang-cabang. Seperti layaknya tanaman darat pada umumnya, rumput laut juga memiliki klorofil atau pigmen warna yang lain. Rumput laut dapat diklasifikasikan menjadi 3 divisi berdasarkan kandungan pigmennya yang digunakan dalam proses fotosintesis, yaitu: Chlorophyta (hijau), Phaeophyta (cokelat) dan Rhodophyta (merah).
Rumput laut dari jenis algae merah lebih banyak dibudidayakan dibandingkan rumput laut dari jenis algae hijau dan coklat. Untuk algae coklat baru Sargasum yang mendapatkan perhatian, itupun masih sebatas penelitian, sedangkan untuk usaha budidaya sampai saat ini belum dikembangkan. Algae coklat menghasilkan Alginat. Sementara itu rumput laut merah khususnya jenis Eucheuma menghasilkan polisakarida dalam bentuk Agar dan Karagenan. Kedua polisakarida ini banyak dimanfaatkan di berbagai bidang industri. Oleh karena itu mereka mempunyai nilai secara ekonomis cukup tinggi. Dan permintaan pasar dunia akan kedua polisakarida tersebut dari tahun ketahun mengalami peningkatan. Secara 
umum ketiga hasil metabolit sekunder tiga jenis rumput laut di atas memiliki fungsi yang sama dalam dunia industri yaitu digunakan sebagai bahan pengental, pensuspensi, penstabil dan pengemulsi. Pemanfaatan rumput laut sebagai bahan makanan, kosmetika dan obat-obatan tradisional sudah lama dikenal oleh masyarakat. Sedangkan pemanfaatannya sebagai bahan industri yang memungkinkan untuk diekspor atau bahkan sebagai bahan energi alternatif (blue ocean energy) baru berkembang dalam beberapa tahun terakhir ini, sehingga merangsang pengembangan untuk budidaya rumput laut. (Natalia dkk, 2014).

Karagenan merupakan senyawa yang termasuk kelompok polisakarida galaktosa hasil ekstraksi dari rumput laut. Sebagian besar karagenan mengandung natrium, magnesium, dan kalsium yang dapat terikat pada gugus ester sulfat dari galaktosa dan kopolimer 3,6anhydro-galaktosa. Karagenan banyak digunakan pada sediaan makanan, sediaan farmasi dan kosmetik sebagai bahan pembuat gel, perenyah, pengental atau penstabil.

Karagenan dapat diekstraksi dari protein dan lignin rumput laut dan dapat digunakan dalam industri pangan karena karakteristiknya yang dapat berbentuk gel, bersifat mengentalkan, dan menstabilkan material utamanya. Karagenan sendiri tidak dapat dimakan oleh manusia dan tidak memiliki nutrisi yang diperlukan oleh tubuh. Oleh karena itu, karagenan hanya digunakan dalam industri pangan karena fungsi karakteristiknya yang dapat digunakan untuk mengendalikan kandungan air dalam bahan pangan utamanya, mengendalikan tekstur, dan menstabilkan makanan.(Iinparlina,2009).

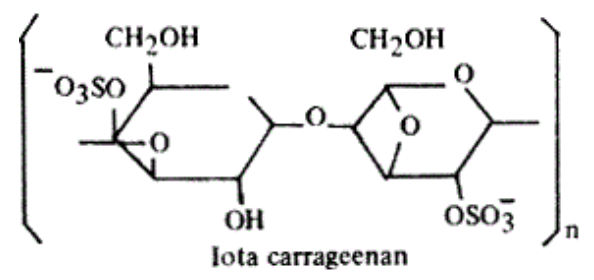

Gambar 1. Struktur Karaginan

\section{METODOLOGI}

Bahan :

Rumput laut, $\mathrm{KOH}$, Aquades, Etanol

Alat:

Timbangan analitis, gunting, labu takar $50 \mathrm{ml}$, gelas beaker, sendok, gelas arloji, pengaduk kaca, statif dan klem, kompor, thermometer, gelas beaker, saringan, gelas beaker $1000 \mathrm{ml}$, kain saring, nampan

\section{Prosedur Kerja \\ Pengeringan dan perendaman Rumput Laut (Eucheuma Cottoni)}

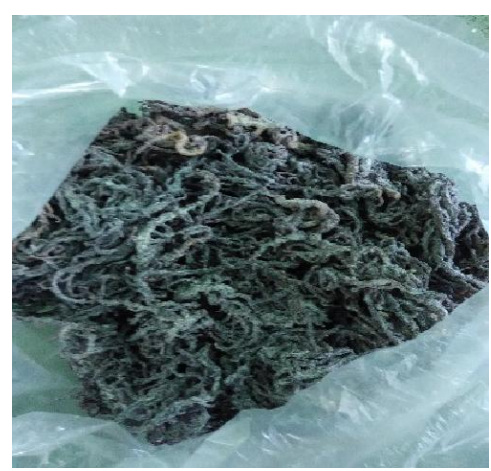

\section{Gambar 2 Rumput Laut Kering}

Mencuci bersih Eucheuma Cottoni dengan air kranuntuk menghilangkan kotorankotoran yang menempel, kemudian memotongmotong rumput laut dengan ukuran yang kecil.Menjemur Eucheuma Cottoni di bawah sinar matahari sampai kering. Merendam 5 gram Eucheuma Cottoni kering dengan larutan $\mathrm{KOH} 0,2 \mathrm{~N}$ agar menambah sifat gelling pada produk karagenan. Setelah 24 jam dilanjutkan dengan pemanasan pada suhu $60^{\circ} \mathrm{C}$ selama 30 menit. Kemudian rumput laut dicuci dengan air kran untuk menghilangkan sisa sisa alkali yang masih tersisa hingga didapat $\mathrm{pH}$ netral.

\section{Ekstrasi Karagenan}

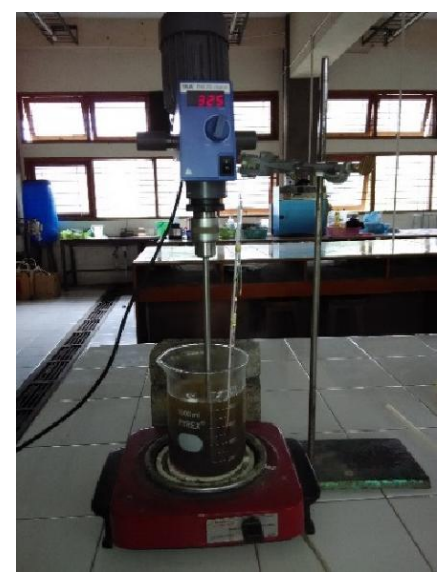

\section{Gambar 3. Ekstraksi Karagenan}

Merangkai alat ekstraksi. Rumput laut yang telah direndam dengan $\mathrm{KOH}$ diekstraksi dengan menggunakan pelarut aquadest 
sebanyak $250 \mathrm{~mL}$ dalam gelas beker. Proses ekstraksi dilakukan selama 1 jam pada suhu 80$90^{\circ} \mathrm{C}$ dan menjaga volume konstan dengan menambahkan aquadest panas setiap volume berkurang. Sambil dilakukan pengadukan dengan motor pengaduk untuk mempercepat proses reaksi.Menyaring hasil ekstraksi dengan saringan sehingga didapatkan filtrat berisi karagenan dan air.

\section{Presipitasi}

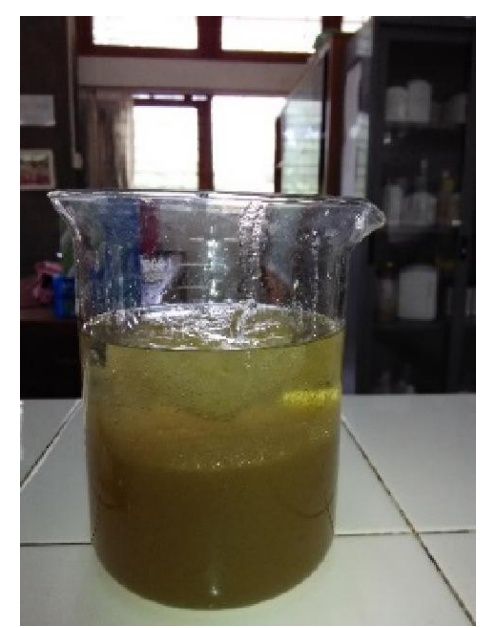

\section{Gambar 4. Proses Presipitasi}

Melakukan proses presipitasi dengan menambahkan alkohol teknis $96 \%$ pada filtrat campuran sebanyak 3:1. Alkohol yang ditambahkan bersuhu rendah. Menyaring hasil presipitasi dengan menggunakan kain saring sehingga didapatkan karagenan basah. Gel karagenan dipanaskan selama 30 menit pada suhu $80-90^{\circ} \mathrm{C}$ untuk menguapkan alcohol yang bercampur dengan karagenan.

\section{Pengeringan dan penepungan}

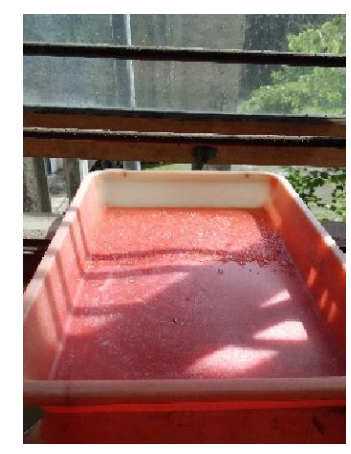

\section{Gambar 5. Proses Pengeringan}

Karagenan basah dituang pada nampan dan dijemur di bawah terik matahari.
Karagenan yang sudah kering diambil dan ditempungkan dengan cara ditumbuk maupun di blender (Sperisa Distantina, 2012).

\section{Cara Analisis}

Analisis Kadar Air (Anonim, 2006)

Memanaskan cawan porselin dalam oven, suhu $105^{\circ} \mathrm{C}$ selama 30 menit, lalu didinginkan dalam desikator selama 15 menit, kemudian ditimbang. Kemudian menimbang sampel sebanyak 1 gram dan dimasukkan dalam cawan porselin. Sampel dipanaskan dalam suhu $105^{\circ} \mathrm{C}$, didinginkan dalam desikator kemudian ditimbang. Ulangi pemanasan dan pendinginan hingga di dapat berat konstan.

Kadar Air $=\frac{A-B}{C} \times 100 \%$

Dimana : $\mathrm{A}=$ Berat cawan porselin + sampel

$\mathrm{B}=$ Berat cawan porselin + sampel setelah dipanaskan

$\mathrm{C}=$ Berat sampel

Analisis kadar abu (Anonim, 2006)

Penentuan kadar abu didasarkan menimbang sisa mineral sebagai hasil pembakaran bahan organik. Kurs porselin dikeringkan di dalam oven selama 1 jam pada suhu $105^{\circ} \mathrm{C}$ lalu didinginkan selama 30 menit di dalam desikator dan ditimbang hingga didapatkan berat tetap (A). Ditimbang contoh sebanyak 2 gram (B), dimasukkan ke dalam kurs porselen dan dimasukkan ke dalam tanur listrik (furnace) dengan suhu $650^{\circ} \mathrm{C}$ selama \pm 12 jam. Selanjutnya cawan didinginkan selama 30 menit pada desikator. Kemudian ditimbang hingga didapatkan berat tetap (C).

Kadar Abu $(\%)=\frac{(A+B)-A}{C} \times 100 \%$

Analisis Kadar Sulfat (Sperisa Distantina, 2010)

Timbang sampel sebanyak W gram. Lakukan proses hidrolisis dengan menambahkan $50 \mathrm{~mL} \mathrm{HCl} 1 \mathrm{~N}$ pada sampel di dalam Erlenmeyer, tutup dengan alumunium foil. Didihkan campuran selama 30 menit. Tambahkan akuades panas sehingga volume tetap $50 \mathrm{~mL}$. Tambahkan $\mathrm{BaCl}_{2}$ 0,25 M $10 \mathrm{~mL}$ dengan cara diteteskan sedikit demi sedikit sambal didihkan selama 5 menit. Dinginkan larutan pada suhu kamar minimal 5 jam. Saring dengan kertas saring (Whatman No.42Ashless) dan cuci dengan akuades. Keringkan sampel dalam kurs porselin. Abukan dalam furnace $700^{\circ} \mathrm{C}$ selama $1 \mathrm{jam}$. Esoknya hitung berat abu 
(W2) dan hitung kandungan sulfat dengan rumus :

$\%$ Sulfat $=(\mathrm{W} 2 / \mathrm{W} 1) \times 100 \times 0,4116$

Kemurnian (BPSMB, 2015)

Uji kemurnian tepung karagenan dilakukan dengan cara Gravimetri. Larutkan sejumlah tepung karagenan dalam akuades. Suhu larutan $24^{\circ} \mathrm{C}$ dan kelembaban $76 \%$. Larutan disaring dengan menggunakan kertas saring, Kemudian keringkan kertas saring tersebut dalam oven. Timbang bahan pengotor yang ada di kertas saring. Kemurnian dapat dicari dengan rumus berikut :

$$
\%_{0}\left(\frac{b}{b}\right)=\frac{B 2-E 1}{B 1} \times 100 \%
$$

\section{Kandungan Etanol (BPSMB, 2015)}

Pengujian kandungan etanol pada tepung karagenan dilakukan dengan test Iodoform. Timbang $5 \mathrm{~mL}$ sampel, tambahkan dengan $\mathrm{NaOH} 10 \%$ dan beberapa tetes $\mathrm{I}_{2}$ dalam KI. Amati perubahan larutan (warna dan endapan).

\section{Uji Organoleptik}

Analisis uji organoleptik pembuatan tepung karagenan dari rumput laut jenis Eucheuma Cottoni dilakukan dengan menggunakan kuisioner (lampiran) yang diberikan kepada 20 orang responden, setiap responden diharuskan memberi penilaian terhadap sampel biskuit yang telah dibubuhi tepung karagenan dan biskuit tanpa diberi tepung karagenan dari rumput laut jenis Eucheuma Cottoni. Sampel biskuit tersebut diteliti berdasarkan tingkat rasa dan tingkat kerenyahan.

\section{PEMBAHASAN}

\section{Analisis Rendemen}

Percobaan dilakukan beberapa kali sampai kebutuhan rendemen karagenan terpenuhi untuk pengujian dan pengemasan. Rendemen rata-rata diambil dari tiga kali percobaan. Rendemen rata-rata yang diperoleh adalah $=34,30 \%$

\section{Analisis Uji Proksimat}

Analisis uji proksimat dilakukan untuk mengetahui kandungan tepung karagenan yang dihasilkan. Analisis tersebut meliputi pengujian kadar air, kadar abu, dan kadar Sulfat.

\section{Kadar Air}

Kadar air merupakan banyaknya air yang terkandung dalam bahan yang dinyatakan dalam persen. Kadar air juga salah satu karakteristik yang sangat penting pada bahan pangan, karena air dapat mempengaruhi panampakan, tekstur, dan citarasa pada bahan pangan. Kadar air dalam bahan pangan ikut menentukan kesegaran dan daya awet bahan pangan tersebut, kadar air yang tinggi mengakibatkan mudahnya bakteri, kapang, dan khamir untuk berkembang biak, sehingga akan terjadi perubahan pada bahan pangan (Winarno, 1997).

Kadar air dalam tepung karagenan yang dihasilkan berdasarkan uji proksimat yaitu $10,32 \%$. Menurut standar mutu karagenan, kadar air maksimal pada tepung karagenan sebesar $12 \%$, sehingga pada penelitian ini tepung karagenan masuk kualifikasi standar mutu dan layak untuk dikonsumsi.

\section{Kadar Abu}

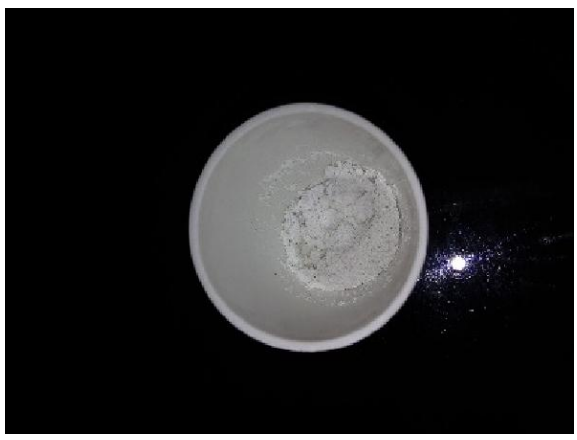

\section{Gambar 6. Uji Kadar Abu}

Kadar abu merupakan campuran dari komponen anorganik atau mineral yang terdapat pada suatu bahan pangan. Sebagian besar bahan makanan, yaitu sekiatar $96 \%$ terdiri dari bahan anorganik dan air. Sisanya terdiri dari unsur-unsur mineral. Unsur juga dikenal sebagai zat organik atau kadar abu. Kadar abu tersebut dapat menunjukan total mineral dalam suatu bahan pangan. Bahan-bahan organik dalam proses pembakaran akan terbakar tetapi komponen anorganiknya tidak, karena itulah disebut sebagai kadar abu.

Kadar abu atau mineral merupakan bagian serta mineral dari bahan yang didasarkan atas berat keringnya. Abu yaitu zat organik yang tidak menguap, sisa dari proses pembakaran atau hasil oksidasi. Penentuan kadar abu ada hubungannya dengan mineral suatu bahan (Winarno, 2002). 
Dalam percobaan kadar abu tepung karagenan yang diperoleh sebesar 15,81\%. Menurut standar mutu karagenan, kadar abu maksimal pada tepung karagenan sebesar 35\%, sehingga pada penelitian ini tepung karagenan masuk kualifikasi standar mutu dan layak untuk dikonsumsi.

\section{Kadar Sulfat}

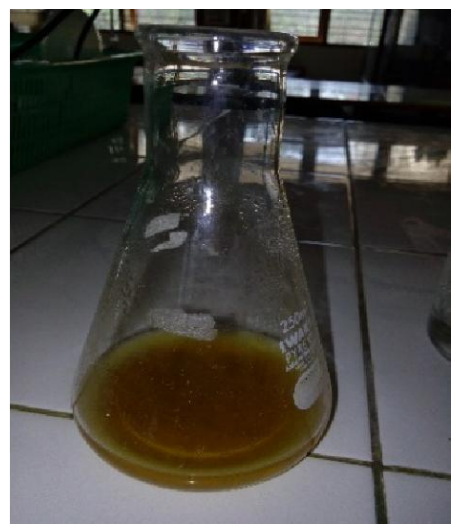

Gambar 7.Uji Sulfat

Penentuan kadar sulfat dalam karagenan dilakukan untuk mengetahui jenis karagenan. Kadar sulfat dalam tepung karagenan yang dihasilkan berdasarkan pengujian yaitu 26,14 $\%$. Menurut standar mutu karagenan, kadar sulfat pada tepung karagenan berkisar antara $18-40 \%$, sehingga pada penelitian ini tepung karagenan masuk kualifikasi standar mutu dan layak untuk dikonsumsi.

\section{Analisis Uji Kemurnian Karagenan}

Uji kemurnian dilakukan untuk mengetahui jumlah zat pengotor yang ada dalam tepung karagenan. Dari hasil pengujian dengan cara gravimetri tidak ditemukan zat pengotor pada tepung karagenan sehingga tepung karagenan layak dan aman untuk dikonsumsi (sebagai bahan tambahan makanan).

\section{Analisis Kandungan Etanol}

Uji kandungan etanol penting dilakukan pada tepung karagenan karenan jika kandungan etanol pada suatu bahan tambahan makanan terlalu tinggi tidak baik untuk dikonsumsi. Dari hasil pengujian tepung karagenan, kandungan etanol negative yang berarti tidak terkandung etanol dalam tepung karagenan sehingga tepung karagenan layak untuk dikonsumsi (dijadikan sebagai bahan tambahan makanan).
Berikut adalah tabel data hasil analisis uji pada tepung karagenan :

\section{Tabel 1. Hasil Uji Proksimat}

\begin{tabular}{|c|c|c|}
\hline $\begin{array}{l}\text { Macam } \\
\text { Analisis }\end{array}$ & $\begin{array}{c}\text { Hasil } \\
\text { Analisis } \\
(\% \mathbf{\%})\end{array}$ & $\begin{array}{c}\text { Standar } \\
\text { mutu } \\
\text { karagenan } \\
(\% w b)\end{array}$ \\
\hline Kadar Air & 10,32 & Maks $12 \%$ \\
\hline Kadar Abu & 15,81 & Maks 35\% \\
\hline Kadar Sulfat & 26,14 & $18-40 \%$ \\
\hline Kemurnian & $\begin{array}{l}\text { Tidak ada } \\
\text { zat } \\
\text { pengotor }\end{array}$ & $\begin{array}{l}\text { Tidak ada zat } \\
\text { pengotor }\end{array}$ \\
\hline Etanol & 0 & Maks 1\% \\
\hline
\end{tabular}

\section{Hasil Pembuatan Kue Kering}

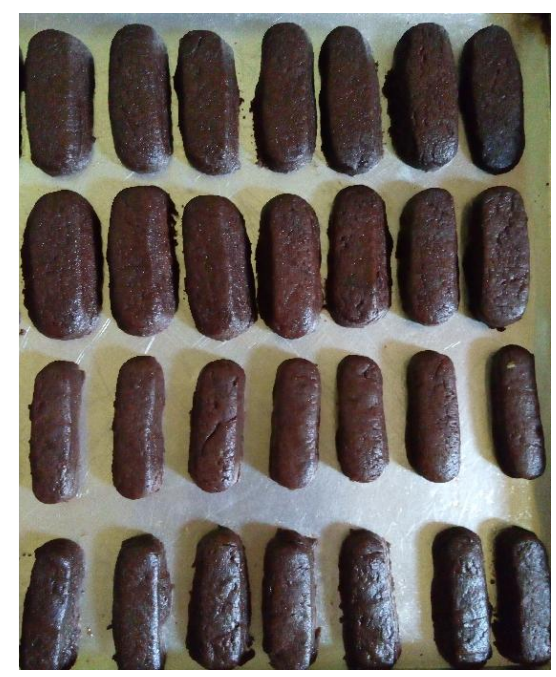

\section{Gambar 8. Produk Biskuit Kering dengan dan tanpa Tepung Karagenan}

Pada gambar diatas dapat dilihat produk biskuit kering yang menggunakan tepung karagenan (2 baris teratas) lebih mengembang dan bervolume daripada produk biskuit kering tanpa tepung karagenan ( 2 baris terbawah).

\section{Analisis Uji Organoleptik}

Tepung karagenan yang dihasilkan kemudian diaplikasikan dalam pembuatan kue kering, dengan membandingkan kue kering yang ditambahkan karagenan dan yang tidak ditambahkan karagenan. 
Kemudian dilakukan penilaian oleh responden meliputi kategori tekstur, aroma, rasa, bau dan kesukaan. Ada 20 responden yang akan melakukan uji organoleptik terhadap kue kering yang ditambahkan dengan tepung karagenan dengab yang tidak ditambahkan tepung karagenan.

Tabel 2. Presentase Hasil Uji Organoleptik terhadap Kue Kering

\begin{tabular}{llll}
\hline \multirow{2}{*}{$\begin{array}{l}\text { Kategori } \\
\text { Aplikasi }\end{array}$} & \multicolumn{3}{c}{ Presentase (\%) } \\
\cline { 2 - 4 } & $\begin{array}{l}\text { Aroma } \\
\text { (Harum) }\end{array}$ & $\begin{array}{l}\text { Rasa } \\
\text { (Enak) }\end{array}$ & $\begin{array}{l}\text { Tekstur } \\
\text { (Renyah) }\end{array}$ \\
\hline $\begin{array}{l}\text { Dengan } \\
\text { Tepung }\end{array}$ & 85 & 90 & 100 \\
$\begin{array}{l}\text { Karagenan } \\
\text { Tanpa }\end{array}$ & 75 & 100 & 70 \\
$\begin{array}{l}\text { Tepung } \\
\text { Karagenan }\end{array}$ & & & \\
\hline
\end{tabular}

Dari tabel 2 dapat diketahui bahwa biskuit kering yang dibuat dengan campuran tepung karagenan dibandingkan dengan biskuit kering yang dibuat tanpa campuran tepung karagenan mendapatkan respon yang berbedabeda dari responden.

Pada biskuit kering yang diberi tepung karagenan menghasilkan produk biskuit yang lebih renyah daripada biskuit kering tanpa tepung karagenan. Karena penggunaan tepung karagenan yang bersifat emulsifier dapat meningkatkan mutu biskuit dan makanan beragi. Penggunaan emulfisier yang bersifat mengaerasi roti menyebabkan makanan akan mekar berongga udara menjadikan volume biskuit akan membesar yang menyebabkan kue menjadi renyah, tekstur lebih lunak dan halus, serta tidak berkerak.

\section{KESIMPULAN}

bahwa :

Dari percobaan ini dapat disimpulkan

Bahan baku pembuatan tepung karagenan adalah rumput laut Eucheuma Cottonii.

Berikut hasil analisis uji tepung karagenan :

- Rendemen

: $34,30 \%$

- Kadar air

: $10,32 \%$

- Kadar abu

: $15,81 \%$

- Kadar sulfat

: $26,14 \%$

- Kemurnian

: Bebas zat pengotor

- Kadar etanol

: $0 \%$

Tepung karagenan dapat diaplikasikan dalam pembuatan biskuit kering. Dengan pembubuhan tepung karagenan ke dalam adonan kue yang dihasilkan menjadi lebih renyah.

\section{SARAN}

Lebih teliti dalam menjaga suhu saat proses berlangsung agar hasil lebih maksimal.

Diperlukan alat yang lebih besar dan kompleks untuk membuat tepung karagenan dalam skala industri.

\section{DAFTAR PUSTAKA}

Anonim. (2011). Rumput Laut. Pusat Penyuluhan Kelautan dan Perikanan: Jakarta

Distantina dkk. (2012). Hydrogel Based on Glutaraldehyde-Crosslinked Kappa Carrageenan: Effect of Glutaraldehyde Concetration. Sebelas Maret Surakarta: Bali

Distantina dkk. (2010). Proses Ekstraksi Karagenan dari Eucheuma Cottonii”. Universitas Diponegoro: Semarang

Natalia dkk. (2014). Makalah Ekologi Laut Ekosistem Rumput Laut diakses tanggal 17 Mei 2015

Parlina, Iin. (2009). Karagenan, produk olahan rumput laut merah Indonesia yangsangat bermanfaat. https://iinparlina.wordpress.com/2009/06 /12/karagenan-produk-olahan-rumputlaut-merah-indonesia-yang-sangatbermanfaat/ diakses tanggal 17 Mei 2015 